\title{
LAXMANNIA MORRISII KEIGHERY (ANTHERICACEAE) A SYNONYM OF L. SQUARROSA LINDL., NOT A NATIVE OF TASMANIA
}

\author{
by D. I. Morris
}

(with two plates)

MORRIS, D. I., 2004 (29:x): Laxmannia morrisii Keighery (Anthericaceae) a synonym of L. squarrosa Lindl., not a native of Tasmania. Papers and Proceedings of the Royal Society of Tasmania 138: 35-36. https://doi.org/10.26749/rstpp.138.35 ISSN 0080-4703. Tasmanian Herbarium, Private Bag 4, Hobart, Tasmania 7001, Australia.

Laxmannia morrisii Keighery is a synonym of Laxmannia squarrosa Lindl. The type specimen of L. morrisii was mistakenly believed to have been collected in Tasmania but was later found to be part of a collection from Western Australia.

Key Words: Liliaceae, Anthericaceae, Laxmannia.

\section{INTRODUCTION}

In the course of preparation of the account of the Liliaceae for Part 4B of The Student's Flora of Tasmania (Curtis \& Morris 1994), an unmounted specimen of a Laxmannia was found in the collection at the Tasmanian Herbarium (HO) (pl. 1). Accompanying the specimen was a note in the handwriting of Dr Winifred Curtis giving the collection details "W.D.J. Snug Plains or Middlesex Plains ? Jan 1960". "W.D.J." referred to Professor William D. Jackson. A later addition to the note indicated that Professor Jackson thought that it may have been collected at Snug Plains, probably near Grey Mountain.

The Laxmannia was not $L$. orientalis Keighery, the only known Tasmanian species, and did not agree with the description of any species of the genus from southeastern

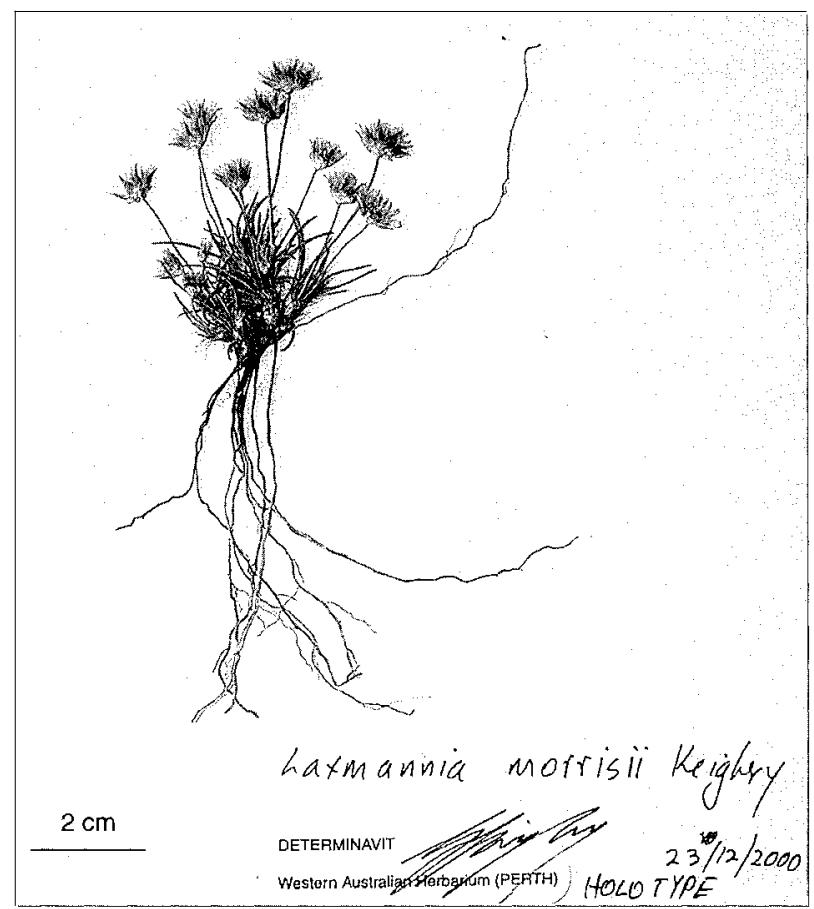

PIATE 1 - Laxmannia morrisii $H$
Australia. Searches in the Grey Mountain area failed to find more of the plant and the matter was set aside awaiting clarification.

In 1999 when Mr G. J. Keighery, the author of the account of Laxmannia in the Flora of Australia, vol. 45 (Keighery 1987), was in Hobart he was shown the unidentified specimen. He requested a loan and subsequently published the new species $L$. morrisii Keighery based on this single specimen (Keighery 2002).

In 2003 some unmounted specimens collected by E. Kalmborg from Western Australia in 1938 were incorporated into HO. Two specimens with a label bearing the information "Camp 2 1./2 miles North of Mt Ross, 18.10.38. Tallanalla District" closely resembled L. morrisii (pl. 2). I examined the specimens and using Keighery's key and description in the Flora of Australia determined them as L. squarrosa

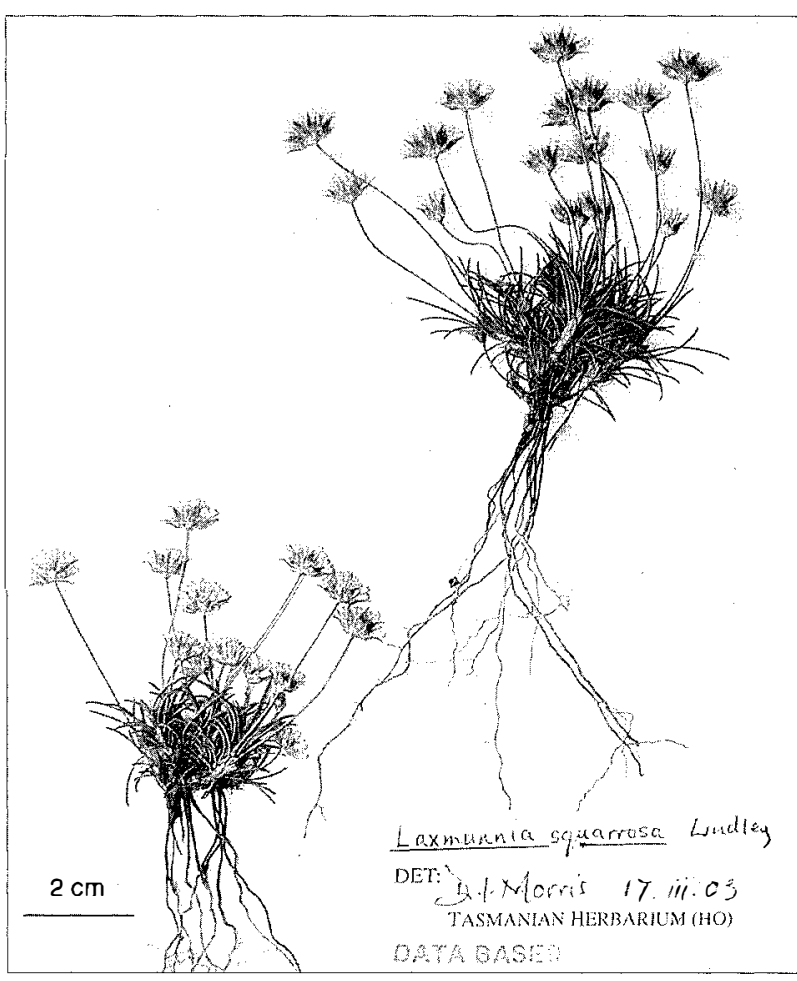

PLATE 2 - Laxmannia squarrosa H@ 326387. 
Lindl. The specimens were identical in all characters with the $L$. morrisii. In his original description of L. morrisii in Nuytsia Keighery had noted that "The plant is superficially very similar in appearance to some forest populations of Laxmannia squarrosa" (Keighery 2002: 378).

\section{DISCUSSION}

There appears to be little doubt that the Western Australian specimens and the L. morrisii specimen are part of the same collection by E. Kalmborg. It would seem that at some stage, perhaps in 1960, the L. morrisii specimen became separated from the two others in the folder and was mistakenly taken to be a collection by Professor Jackson who, when asked many years later, had no clear recollection of having made the collection. Consequently, L. morrisii is to be regarded as a synonym of $L$. squarrosa and should be deleted from the Census of the Vascular Plants of Tasmania, and the type details in Australian Plant Name Index must be corrected.

\section{ACKNOWLEDGEMENTS}

I acknowledge with gratitude the contribution of Alex Buchanan, who drew my attention to the Kalmborg collection, and that of Lyn Cave, who produced the photographs.

\section{REFERENCES}

CurTis, W. M. \& Morris, D. I., [1994] 1995: The Student's Flora of Tasmania, Part $4 B$. St David's Park Publishing, Hobart, Tasmania.

KeIGHeRY, G.J., 1987: Laxmannia. Flora of Australia 45: 254-264. Australian Government Publishing Service, Canberra.

KergherY, G.J., 2002: A new species of Laxmannia (Anthericaceae) from Tasmania and a new subspecies from Western Australia. Nuytsia 14(3): 375-380.

(accepted 22 March 2004) 